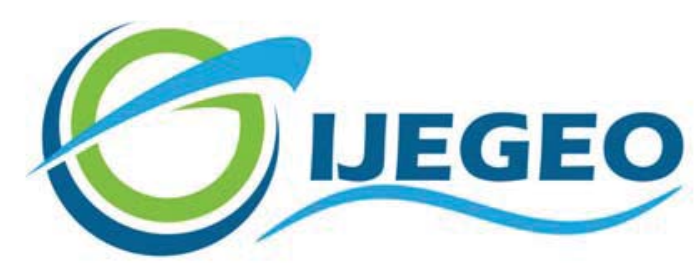

International Journal of Environment and Geoinformatics (IJEGEO) is an international, multidisciplinary, peer reviewed, open access journal.

\title{
Geoarchaeological evidence of the Late Chalcolithic circular structure at Ovçular Tepesi in Nakhchivan
}

\section{Savaş SARIALTUN}

\author{
Chief in Editor \\ Prof. Dr. Cem Gazioğlu \\ Co-Editors \\ Prof. Dr. Dursun Zafer Şeker, Prof. Dr. Şinasi Kaya, \\ Prof. Dr. Ayşegül Tanık and Assist. Prof. Dr. Volkan Demir
}

Editorial Committee (December 2021)

Assoc. Prof. Dr. Abdullah Aksu (TR), Assit. Prof. Dr. Uğur Algancı (TR), Prof. Dr. Bedri Alpar (TR), Assoc. Prof. Dr. Aslı Aslan (US), Prof. Dr. Levent Bat (TR), Prof. Dr. Paul Bates (UK), İrşad Bayırhan (TR), Prof. Dr. Bülent Bayram (TR), Prof. Dr. Luis M. Botana (ES), Prof. Dr. Nuray Çağlar (TR), Prof. Dr. Sukanta Dash (IN), Dr. Soofia T. Elias (UK), Prof. Dr. A. Evren Erginal (TR), Assoc. Prof. Dr. Cüneyt Erenoğlu (TR), Dr. Dieter Fritsch (DE), Prof. Dr. Çiğgem Göksel (TR), Prof.Dr. Lena Halounova (CZ), Prof. Dr. Manik Kalubarme (IN), Dr. Hakan Kaya (TR), Assist. Prof. Dr. Serkan Kükrer (TR), Assoc. Prof. Dr. Maged Marghany (MY), Prof. Dr. Michael Meadows (ZA), Prof. Dr. Nebiye Musaoğlu (TR), Prof. Dr. Masafumi Nakagawa (JP), Prof. Dr. Hasan Özdemir (TR), Prof. Dr. Chryssy Potsiou (GR), Prof. Dr. Erol Sarı (TR), Prof. Dr. Maria Paradiso (IT), Prof. Dr. Petros Patias (GR), Prof. Dr. Elif Sertel (TR), Prof. Dr. Nüket Sivri (TR), Prof. Dr. Füsun Balık Şanlı (TR), Prof. Dr. Uğur Şanlı (TR), Duygu Ülker (TR), Prof. Dr. Seyfettin Taş (TR), Assoc. Prof. Dr. Ömer Suat Taşkın (TR), Assist. Prof. Dr. Tuba Ünsal (TR), Dr. Manousos Valyrakis (UK), Dr. İnese Varna (LV), Dr. Petra Visser (NL), Prof. Dr. Selma Ünlü (TR), Assoc. Prof. Dr. Oral Yağcı (TR), Prof. Dr. Murat Yakar (TR), Assoc. Prof. Dr. İ. Noyan Yılmaz (AU); Assit. Prof. Dr. Sibel Zeki (TR)

Abstracting and Indexing: TR DIZIN, DOAJ, Index Copernicus, OAJI, Scientific Indexing Services, International Scientific Indexing, Journal Factor, Google Scholar, Ulrich's Periodicals Directory, WorldCat, DRJI, ResearchBib, SOBIAD 
Reaserch Article

\title{
Geoarchaeological evidence of the Late Chalcolithic circular structure at Ovçular Tepesi in Nakhchivan
}

\author{
Savaș Sarialtun \\ Independent Researcher, Çanakkale, Turkey \\ E-mail: savassarialtun@gmail.com
}

Received: 08.02.2021

Accepted:22.08.2021

How to cite: Sarraltun, S. (2021). Geoarchaeological evidence of the Late Chalcolithic circular structure at Ovçular Tepesi in Nakhchivan. International Journal of Environment and Geoinformatics (IJEGEO), 8(4):482-487. doi.10.30897/ijegeo. 876417

\begin{abstract}
This article provides indirect evidence of the function of circular structures by focusing on the sedimentological process of the circular structures by the groups in the Late Chalcolithic period that occupied Ovçular Tepesi in Nakhchivan. Microstratigraphic has gained increasing importance in archaeological research and many studies. It has become an indispensable pillar of research methods, going beyond its role as an auxiliary method. The main scope of this study is considered not only as a way to reveal the physical structure of external factors experienced in the past but also as part of the process of understanding the extent and variability of human-environment interaction in the context of time-space. In addition to the microstratigraphic field studies conducted to determine the sedimentological deposition process of the circular structures in Ovçular Tepesi and to reveal the differentiation range in sedimentation, texture and SEM images and EDX analyzes were also supported in this study. However, this study was focused on the microstratigraphic and microarchaeological data of the Ch.6-346 circular structure which contains the best sedimentological data and sheds light on other circular structures in this sense. Besides, determinations regarding the construction applications of circular structures such as masonry technique, plaster and soil floors were also shared.
\end{abstract}

Keywords: Nakhchivan, Late Chalcolithic, Ovçular Tepesi, Circular Structure, SEM, EDX

\section{Introduction}

Nakhchivan refers to the area east of Mount Ararat, to the left of Aras (Araxes) River and south of the Dereleyez and Zangezur ranges in the Lesser Caucasus Mountains (Zaman, 2014; Firınc1, 1998; Kurt and Özkan, 2017). Therefore, being at the east-west and north-south crossroads in the southern Caucasus, the geopolitical location of Nakhchivan presents an opportunity to communicate not only with the mountainous Anatolian and the Zagros regions but also the Urmia Basin. From Nakhchivan, the shortest and easiest way to reach Anatolia from the east and southeast is the route across wide plains through which the Aras River flows.

Nakhchivan, which is located between southern Caucasia and Iran and Anatolia, geomorphologically includes many different landscapes, from high mountainous areas formed of glacial topography to alluvial plains, and from wetlands to Kirgıbayır characteristic terrain (Özkan, 2016: 39-46). Nakhchivan can be considered as having two morphological structures: the lowland areas on the banks of the Aras River and the mountainous area surrounding it to the north and northeast (Koçman and İbrahimov, 1994). Nakhchivan region can be morphologically classified into three groups: flat areas, hilly areas and high mountainous areas. The lowest elevation of Nakhchivan is 600 meters while the altitude of the highest point, the peak of Mount Kapıcık (Qapıcıq), is 3906 m (Şimşek, 2010:115). The relative difference in elevation around Nakhchivan is 3306 meters. This difference emphasizes the effect of tectonic uplift as well as extreme surface erosion and vertical erosion. The average height of the lowland area around the Aras River is 807 meters, although when the mountainous area to the north is considered, the average height of Nakhchivan reaches 1410 meters.

Ovçular Tepesi is located on a natural hill on the east bank of the Arpaçay stream in the Nakhchivan Autonomous Republic of Azerbaijan (Fig.1). After limited studies were carried out by Azerbaijani archaeologists in 1986 and 2001 (Berthon et al., 2013), systematic scientific excavations commenced in 2006 as part of a Franco-Azerbaijani Joint Project (Marro et al., 2009) and the excavations were completed in 2013.The site has two main archaeological phases, namely, Late Chalcolithic and Kuro-Araxes. The Chalcolithic layers lie directly under an Early Bronze Age cultural deposit which is less well-preserved than the upper level. The second level, representing the Late Chalcolithic period, is divided into two phases. The Phase I is dated to 4350$4250 \mathrm{BC}$ and the Phase II, where the circular structures lie, is dated to 4250-3940 BC (Marro et al., 2009, 2011). 


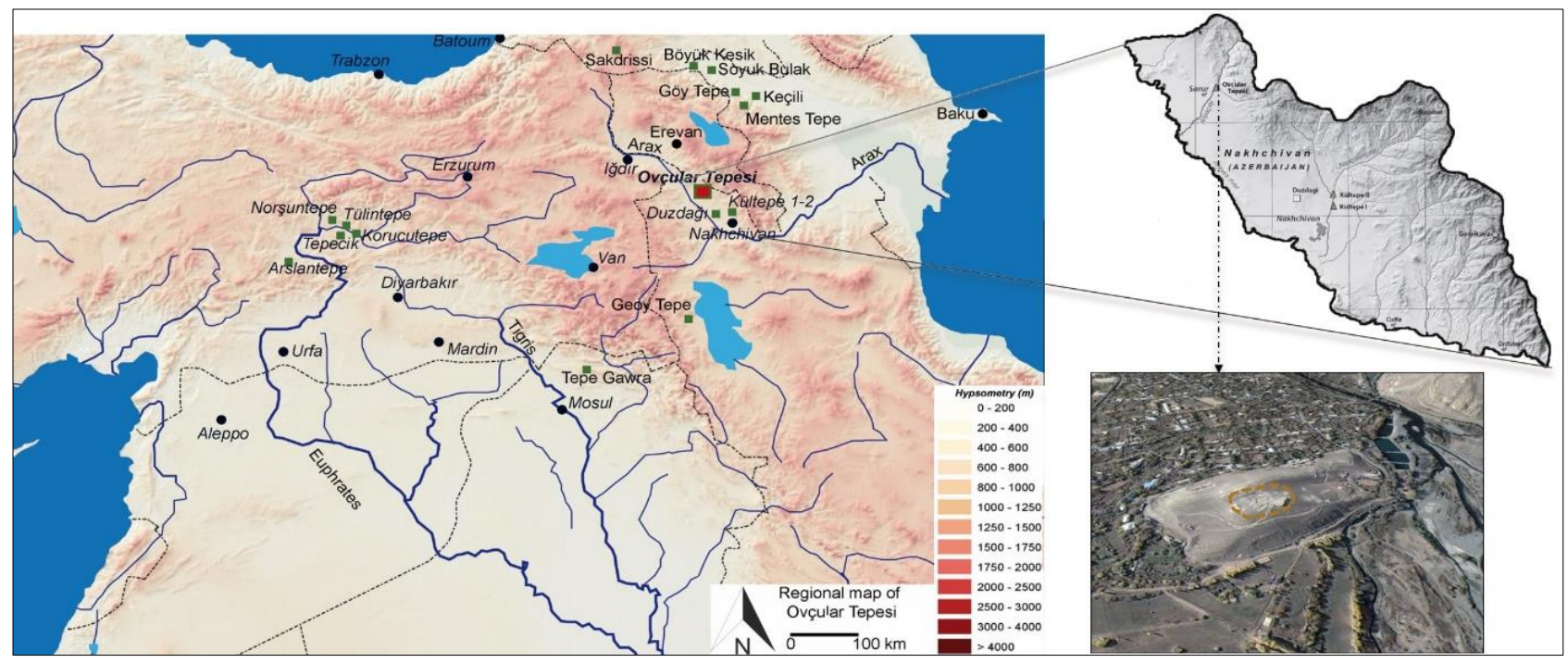

Fig. 1: Map of the study area, showing the location of Ovçular Tepesi

This study concerns indirect evidence of the circular structures belonging to the Late Chalcolithic communities in Nakhchivan. This is important because direct evidence of storage practices by prehistoric societies has rarely been identified due to poor preservation of the organic material and, more probably, due to stored food usually being left only accidentally as archaeological remains. There are many archaeological instances citing the re-use of abandoned storage facilities for other purposes, such as pits.

While Phase II yielded twelve circular structures, five of them in the same horizon were studied with microarchaeological observations using the deposition process. Although these five circular structures have similar deposits, the circular structure Ch.6-346 was the best example with its well-preserved deposition. In other words, the micromorphological study of the structure Ch.6-346 deposit represents the depositional process of all the structures in the same horizon. Unfortunately, we do not have any direct evidence regarding the earliest usage of the structures, since there was multiple utilization. All the we have is the secondary data associated with post-depositional accumulation after the usage of circular structures.

\section{Materials and Methods}

The first stage in the sampling process is to clearly define post-depositional sediment processes in the circular structures. In this context, primarily microstratigraphic variations were determined. Samples of each variability were taken after this initial stage. The layers of accumulation that need to be analyzed after the preliminary examination of the samples taken were subjected to laboratory analysis for further investigations and the filling process of these structures after use was tried to be understood. This study was focused on the microstratigraphic and microarchaeological data of the Ch.6-346 circular structure which contains the best sedimentological data and sheds light on other circular structures in this sense.
Ch. 6-346 circular structure remains were extracted for grain size determination and microanalysis. The element composition and micromorphological features of the soil samples of the Ch. 6-346 were examined using a Phillips XL-30S FEG Scanning Electron Microscope equipped with EDX detector. X-ray Diffractometry (Phillips $\mathrm{X}$ 'Pert Pro) was used to determine the mineral content. The analyses were carried out at İzmir Institute of Technology, Material Research Center (IZTECHMAM).

Soil texture analysis is generally made by using standard sieves having screen openings between 4 millimeters and 38 microns. This method is easy and inexpensive, and the material can be segregated easily. It was performed with a Retsch Automatic Sieve Machine with 8 sieve chambers at the laboratory of Çanakkale Onsekiz Mart University's Archaeology Department. Dry samples which were primarily arranged were weighed by means of an assay balance. Then, their grain size composition was examined by sieving on 8 different scales.

\section{Results and Discussion}

Storage facilities are one of the focal points of archaeological research on prehistoric communities. This socio-economic practice, built to store the obtained product, is an important architectural element in understanding the settlement's styles and strategy (Kuijt, 2011; Binford, 1978). However, direct evidence of prehistoric societies' practices in storing their produce is difficult to detect. Because of the problematic re-use of some architectural structures, which are thought to have been built for storage purposes by different groups after being abandoned, microarchaeological studies are required to reveal the difference between original use and subsequent use. Much archaeological evidence has been identified showing that the architectural structures built for storage purposes were later a garbage site for household waste (Kent, 1999). Thus, the identification of prehistoric storage facilities is mainly based on indirect 
evidence such as plastered or stone-lined pits (BarYosef, 1998) or small enclosed areas (Verhoehen, 1999).

The most abundant material excavated or obtained in an archaeological excavation is not lithic artifacts, pottery or architectural structures. The most common item is the cultural filling in which they are found, namely, the soil (Banning, 2000). These sedimentological units are not a passive element to be screened or ignored, as they preserve unique evidence of the formation processes of the archaeological site, the paleoenvironmental conditions, and the chronology of the settlement. The meaning of the sedimentological contents can also be detected in geoarchaeological data sources such as soil profiles and microstratigraphy from archaeological deposits (Hill and Rapp, 2014; D'Amore, 2014; Matthews, 2003) Therefore, soil can be documented and examined by sedimentologists and micromorphologists to understand how a deposit was formed. Geoarchaeological survey procedures include sediment classification, micromorphology, particle size analysis, and multi-cellular geochemistry (Branch, 2014). Sediment classification, particle size and SEM/EDX analyses were carried out at Ovçular Tepesi to understand the sedimentation process of the soils in the round structures and to determine their properties.

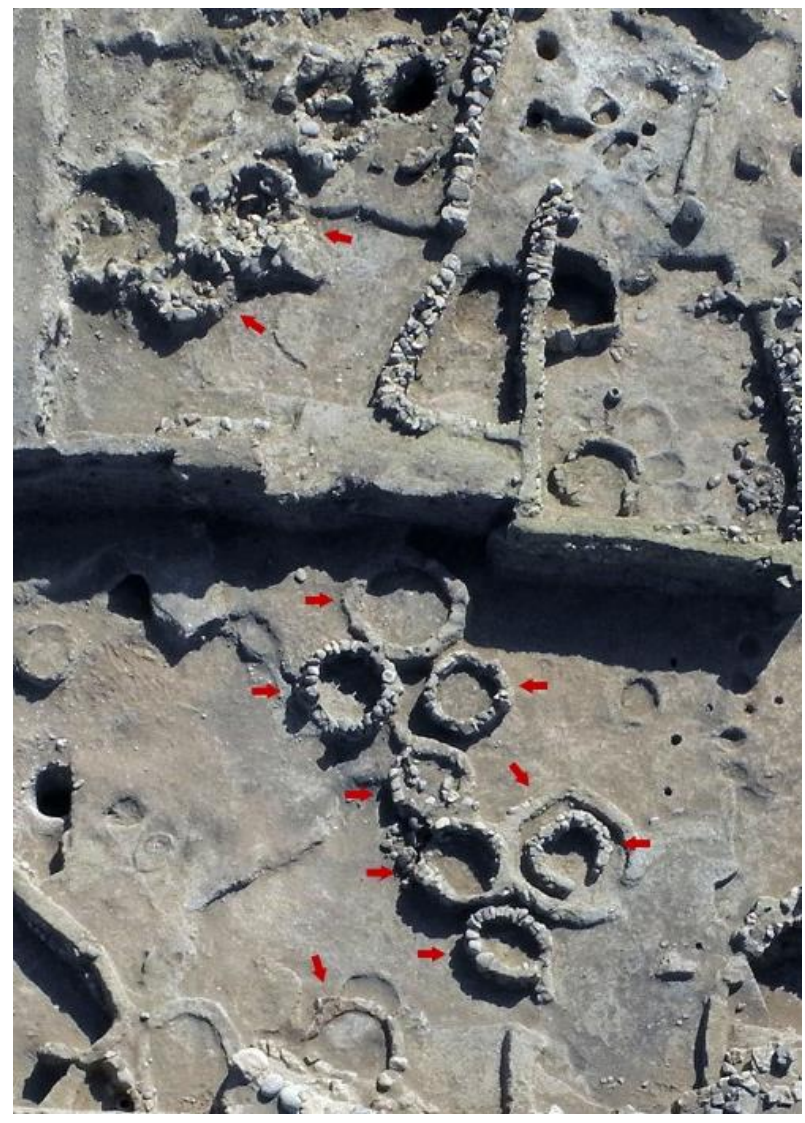

Fig. 2: Locations of circular structures from Ovçular Tepesi excavation area (OT excavation archive)

In this connection, very interesting finds were made between 2009 and 2013 with the discovery of an area possibly dedicated to food-storage in the designated area. A series of circular, stone-walled structures were found in the vicinity of the multi-roomed house from Chantier
12 and most of them are clustered in an apparently outdoor area from Chantier 6, which are the subject of this study (Fig. 2). In addition, they are seen sporadically in the other trench (in french: Chantier). These stone structures all had a narrow opening, usually facing north or west that had been blocked up with a pilled earth wall or sealed with wattle and daub.

An apparent outdoor area from Chantier 6 and Chantier 10 is represented by eight circular structures with internal diameters ranging from $90 \mathrm{~cm}$ to $170 \mathrm{~m}$, which were constructed rather close to each other (Fig. 2, 3a-c). Simple stone footings - in single or double courses- of the structures were fitted directly upon the ground. Even though there is no evidence for the superstructures, the weak construction of the stone footings indicates that the structures were made of perishable materials in Ch.6-346 (Fig. 3c, g).

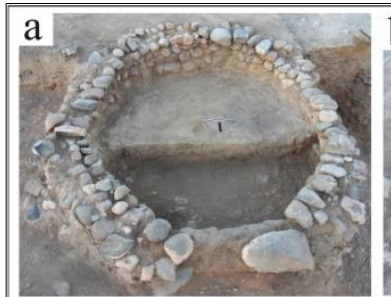

Ch. 10-003

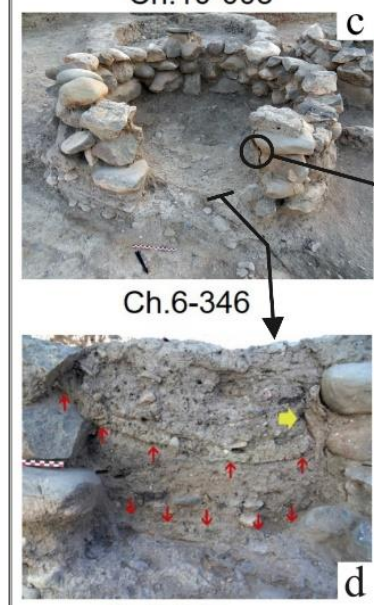

Ch.6-346

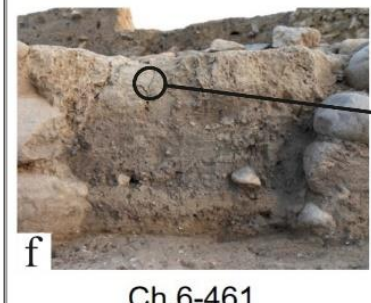

Ch.6-461

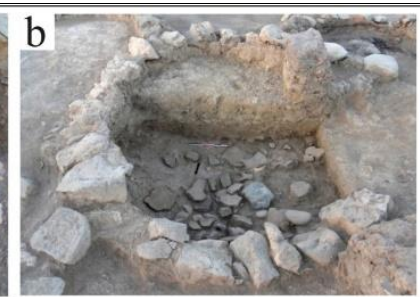

Ch.6-550

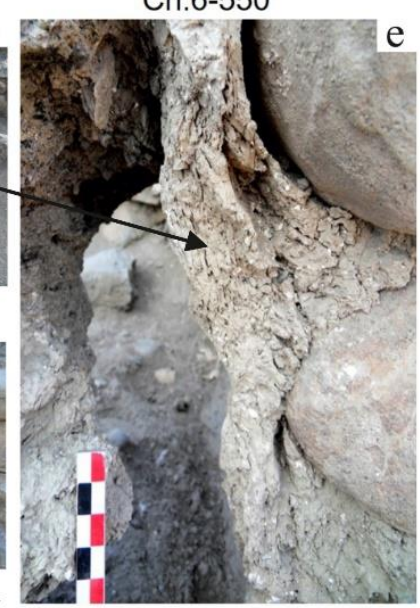

Ch.6-346

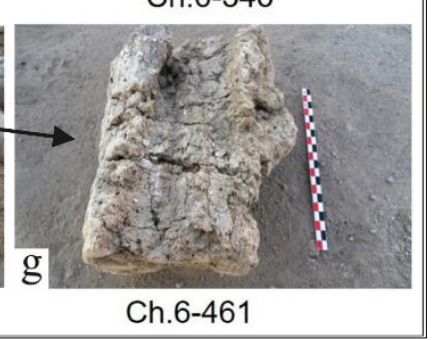

Fig. 3: Examples of circular structures from Ovçular Tepesi

Microarchaeological analyses, including micromorphology, are essential for documenting the composition, preservation, and function of finds. Therefore, these investigations focus on describing the filling and depositional process of these structures. In this initial micromorphological study on the circular structures at Ovçular Tepesi, samples were taken from soils that are not notably associated with possible 
primary deposits and in situ artifacts. Also, the soils appear to be filled with secondary or tertiary deposits, similar to most of the structures recovered at the site. However, we found some in situ artifacts from primary deposits which are made with clay, such as plastered walls and floors (Fig. 3d-e, 4) The primary function of these structures is not known yet but the presence of an opening suggests that they may have been used as some kind of storage facility (Marro, 2011). Sedimentological layers determined in almost all of the structures examined are very different from each other. Nevertheless, we can classify the deposits of the studied samples into two main groups. Generally, the filling on the first floor is homogeneous, while the second floor is not.

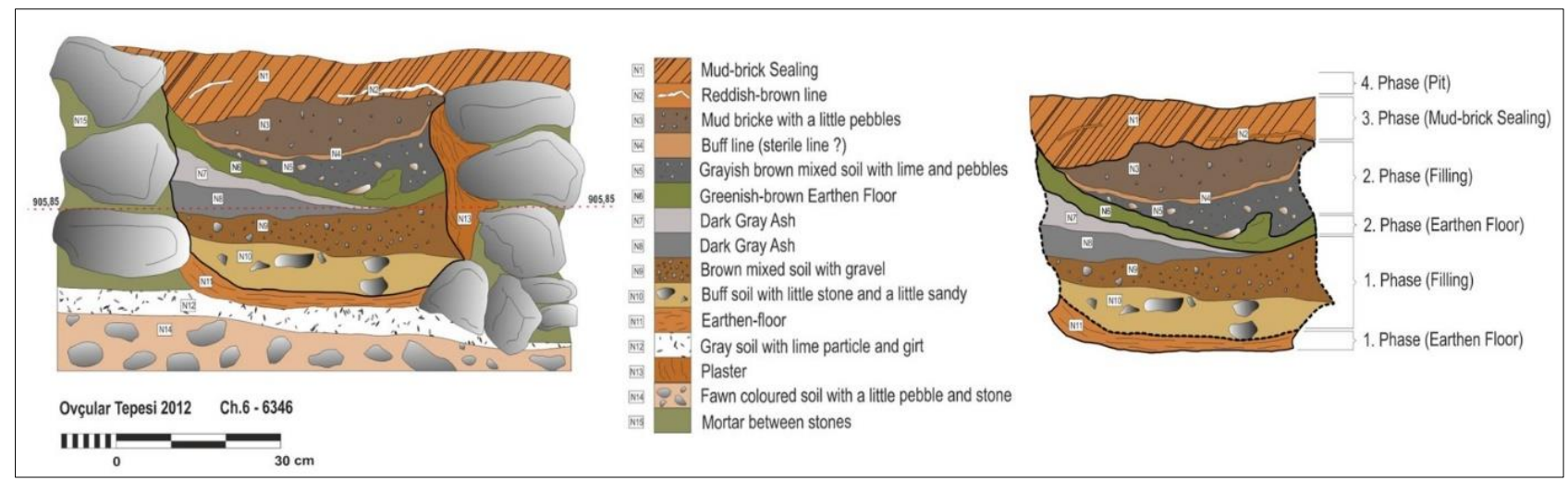

Fig. 4: Fill section microstratigraphic distinction of Ch.6-346 Circular Structure

There is a lot of evidence that the floor and wall surface had been plastered during the first-use stage of the circular structures. When we examined the architectural features and soil sections of these structures, we could not find traces of the superstructure. However, there is evidence that the walls had been plastered. Moreover, the walls had been plastered many times, at least twice (Fig. 3e)

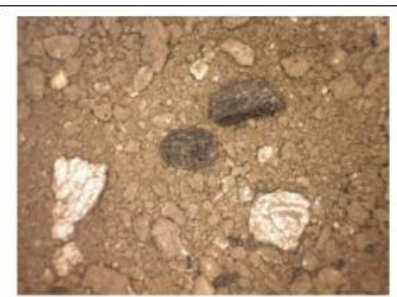

Ch.6-346 N3

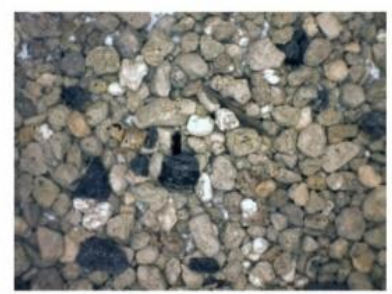

Ch.6-346 N5

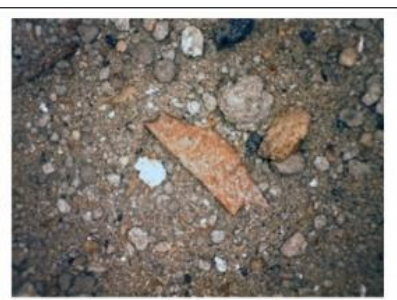

Ch.6-346 N4

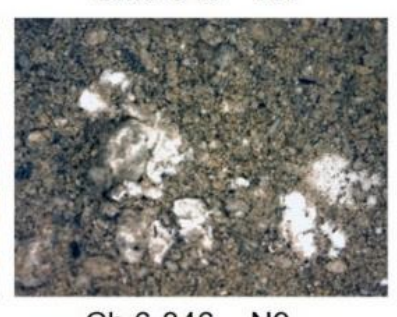

Ch.6-346 N9
Fig. 5: Selected examples of sediment content in Ch.6346 circular structure

Generally, charcoal and calcium carbonate fragments were found in the filling of these structures. Small pieces of animal bones were identified in some samples, and only one sample belonging to a different type of pottery sherd was found (Fig. 3b). As determined in just one sample, the presence of a very pronounced thin layer of soil suggests that such structures remained uncovered, at least for a while. These thin layers resembling mud crusts are formed as a result of the wetting of the soil surface by external factors (e.g. rain) and then sudden drying. In this context, it is not possible to claim that the upper cover was massively and permanently covered for this structure.

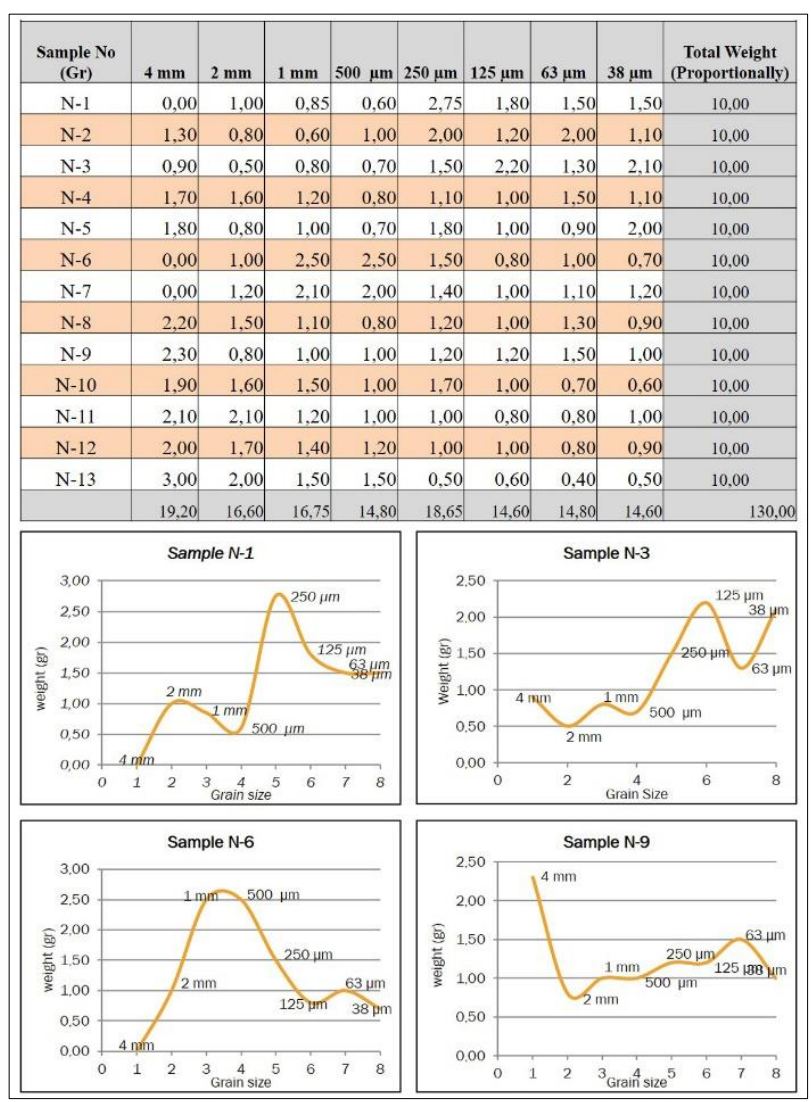

Fig. 6: Soil Texture of Ch.6-346 Circular Structure

According to Texture Analysis, the fine grain size (38$125 \mu \mathrm{m})$ is more dominant than the coarse grain size (1$4 \mathrm{~mm}$ ). The deposits of the circular structures in Ch. 6346 are not only rich in calcium carbonate particles but also charcoal granules (Figs. 5, 6) The size of the 
charcoal particles changes between 1 to $4 \mathrm{~mm}$, pointing to a heavy concentration of organic material in this period. The granulometric frequency distribution graph shows negative skewness in most of the studied samples. These results demonstrate that the fillings are not homogeneous.

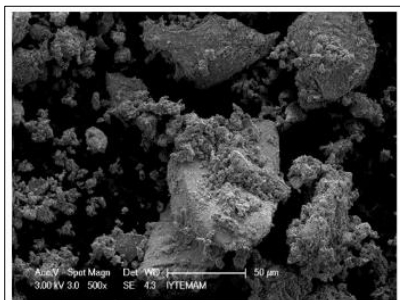

Ch.6-346 N1

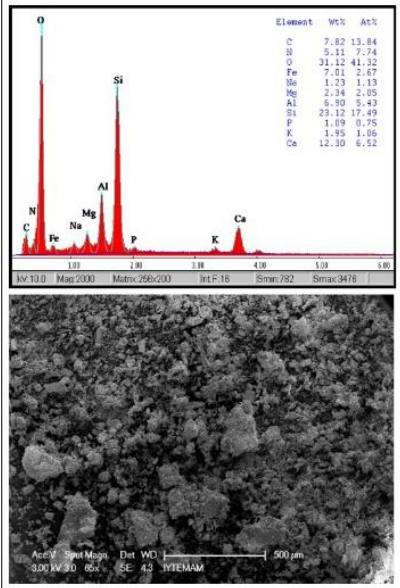

Ch.6-346 N4

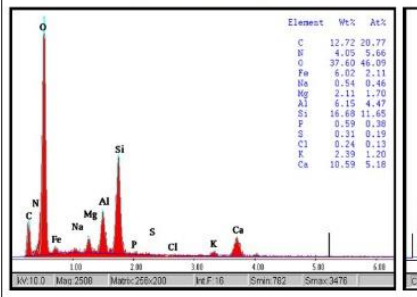

Fig. 7: SEM/EDX analysis of Circular Structure at Ovçular Tepesi

Beside EDX/SEM analysis data, the field observations show that the door fillings of the structures display various accumulations. Some of the deposits have charcoal remnants and animal bones while others have only sand and clay. In particular, the sand varies in shape from smooth and rounded to rough and angular. The fact remains that was also found in the remains of some of the earthen floors. Field observations as well as SEM images show that in Ch. 6-346 circular structure, the filling samples have different grain size and also different mineralogical composition. EDX analyses of the same samples demonstrate predominance of $\mathrm{O}$ (41.01\%), Ca (20.09\%), C (16.64\%) and Si (14.77\%). Besides these, there are also some other minerals in lesser amounts (Fig. 7).

\section{Conclusion}

The results of the Texture and EDX/SEM analyses give some clues as to the accumulation process of the circular structures. The non-homogenous character of the deposits points to multi-usage and various activities. Since the only remains of primary usage are the partlypreserved floors and wall plastering, the function of the circular structures is not yet known. Changes in the accumulation character and the blocking of openings by different methods demonstrate various functions of the structures. After blocking the openings, the circular structures might have been used without permanent cover. We plan to examine the Late Chalcolithic storage dynamics and socioeconomic complexity in more comprehensive and different ways. This will allow us to make more systematic and consistent comments about the Late Chalcolithic communities in the South Caucasus.

\section{Acknowledgements}

This study was carried out under the Franco-Azerbaijan Joint Project by co-directors Prof. Dr Catherine Marro and Prof. Dr Veli Bakhshaliyev. In addition, this study has benefited from the poster work presented in the 41st International Symposium on Archaeometry - ISA2016 "Microarcheological Investigation of Filling Processes of Circular Structures at Ovçular Tepesi: A Late Chalcolithic and Kuro-Araxes Site". I would like to express my gratitude to Prof. Dr. Catherine Marro and Prof. Dr Veli Bakhshaliyev for permitted me to do the study of Ovçular Tepesi. Mr. Graham Lee is thanked for proofreading the English text of the article. I am also indebted to editorial board member and journal referees for their constructive comments that have greatly improved my paper.

\section{References}

Banning, E.B. (2000). Soils, Sediments, and Geomorphology. In: Jochim, M.A. and Dickens, R.S. (Eds), The Archaeologist's Laboratory - The Analysis of Archaeological Data (pp.235-247), Interdiciplinary Constriburions to Archeology book series (IDCA).

Bar-Yosef, O. (1998). The Natufian culture in the Levant, threshold to the origins of agriculture. Evolutionary. Anthropology. 6 (5), 159-177.

Berthon R., Decaix A., Kovács Z. E., Van Neer W., Tengberg M., Willcox G., Cucchi T. (2013). A bioarchaeological investigation of three late Chalcolithic pits at Ovçular Tepesi (Nakhchivan, Azerbaijan). Journal of Environmental Archaeology, 18 (3), 191-200.

Binford, L. (1978). Nunamiut Ethnoarchaeology. Academic Press.

Branch, N. (2014). Agrarian Landscapes: Environmental Archaeological Studies. In: Smith C. (Ed.), Encyclopedia of Global Archeology (pp. 84-90), Springer.

D'Amore, L. (2014). Stratigraphy in Archaeology: A Brief History. In: Smith C. (Ed.), Encyclopedia of Global Archeology (pp. 7085-7094), Springer.

Fırınc1, Ö. (1998). Nahçıvan Özerk Cumhuriyeti'nin Coğrafi Etüdü (Master Thesis). Marmara Üniversitesi, İstanbul, Turkey. 
Hill, C.L., Rapp, G. (2014). Geoarchaeology. In: Smith C. (Ed.), Encyclopedia of Global Archeology (pp. 3008-3017). Springer.

Kent, S. (1999). The Archaeological Visibility of Storage: Delineating Storage from Trash Area. American Antiquity, 64 (1), 79-94.

Koçman A., İbrahimov, A. (1994). Azerbaycan Cografyast. Ege Üniversitesi Edebiyat Fakültesi Yayınları (No:78).

Kuijt, I. (2011). Home is where we keep our food: the origins of agriculture and late Pre-Pottery Neolithic food storage. Paleorient, 37 (1), 137-152.

Kurt, H., Özkan, M. (2017). Bağımsızlıktan Günümüze Nahçivan'ın Zirai Yapısı. Doğu Coğrafya Dergisi, 38, 111-136.

Matthews, R. J. (2003). Excavations at Tell Brak, Exploring an Upper Mesopotamian regional centre, 1994-1996. Mcdonald Institute for Archaeological Research and British School of Archaeology in Iraq.

Marro, C., Bakhshaliyev, V., Ashurov, S. (2009). Excavations at Ovçular Tepesi (Nakhchivan, Azerbaijan) First Preliminary Report: The 20062008 Seasons. Anatolia Antiqua 17, 31-87.

Marro, C., Bakhshaliyev, V., Ashurov, S. (2011). Excavations at Ovçular Tepesi (Nakhchivan, Azerbaijan). Second Preliminary Report: The 20092010 Seasons. Anatolia Antiqua 19, 53-100.

Özkan, M. (2016). Nahçivan'ın Beşerî ve İktisadi Coğrafyas1 (1991-2014) Master Thesis). Marmara Üniversitesi, İstanbul, Turkey.

Şimşek, O. (2010). Nahçıvan'ın Jeopolitik ve Jeostratejik Önemi. Sosyal Bilimler Enstitüsü Dergisi, 6, 111-132.

Verhoehen, M. (1999). An Archaeological Ethnography of a Neolithic Community - Space, Place and Social Relations in the Burnt Village at Tell Sabi Abyad, Syria. Nederlands Historisch-Archaeologisch Instituut Te Istanbul.

Zaman, S. (2014). Siyasi Coğrafya Açısından Nahçıvan Özerk Cumhuriyeti, Pegem Akademi Yayınları 